\title{
Structural and successional variability of periphytic algal community in a Amazonian lake during the dry and rainy season (Rio Branco, Acre)
}

\author{
Raquel C.S. FRANÇA ${ }^{1}$ Maria Rosélia Marques LOPES ${ }^{1}$, and Carla FERRAGUT²
}

\begin{abstract}
The colonization process and successional patterns of a periphytic algal community were evaluated in a Amazonian Viveiro Lake (Rio Branco, Acre, Brazil). Sampling was performed over a period of 35 days; at four-day intervals for 20 days, and then at five-day intervals. Water sampling for physical, chemical and biological analyses was done during the dry and rainy season. Glass slides were used as artificial substrates for periphyton colonization. The structural community was evaluated through population density, algae class, diversity indices and descriptive species. Species richness, diversity and evenness increased as succession progressed. While density of Bacillariophyceae, Euglenophyceae and Zygnemaphyceae increased with succession, Cyanobacteria remained dominant. Synechocystis aquatilis, Synechocystis diplococcus and Navicula pseudolanceolata were the main descriptive species in both the dry and rainy season. Cymbela tumida, Frustulia rhomboides, Trachelomonas lacustris and Closterium acicularis was correlated with an increase in hydrologic level during the rainy season. Conversely, the density of Chlamydomonas sp., Chroomonas nordstedtii, Trachelomonas volvocinopsis, Trachelomonas volvocina and Synechococcus linearis was correlated with an increase in water transparency during the dry season. In general, the periphytic algal community showed high diversity and species richness independent of season. Season also had little influence on representation of algae class and main descriptive species. However, successional patterns varied by season, and changes in hydrologic levels acted directly on the succession path of periphytic algae. More research on periphyton dynamics is needed to improve our understanding of tropical lake ecosystems, especially in Amazonian.
\end{abstract}

KEYWORDS: Periphyton, colonization, succession, diversity

\section{Variação estrutural e sucessional da comunidade de algas perifíticas em lago amazônico durante o período seco e chuvoso}

\section{RESUMO}

A colonização e o modelo sucessional da comunidade de algas perifíticas foram avaliados no amazônico Lago do Viveiro (Rio Branco, Acre, Brasil). Amostragens foram realizadas no período de 35 dias com intervalos de quatro dias nos primeiros 20 dias e cinco dias no final. Foram realizadas amostragens da água para a determinação das variáveis físicas, químicas e biológicas no período seco e chuvoso. Lâminas de vidro foram usadas para a colonização do perifíton. A estrutura da comunidade foi avaliada através da densidade populacional, classes algais, índices de diversidade e espécies descritoras. A riqueza de espécies, diversidade e equitabilidade aumentaram com o avanço da sucessão. A densidade de Bacillariophyceae, Euglenophyceae e Zygnemaphyceae aumentaram com o avanço da sucessão, mas Cyanobacteria permaneceu dominante. Synechocystis aquatilis, Synechocystis diplococcus e Navicula pseudolanceolata foram descritoras da comunidade no período seco e chuvoso. Cymbela tumida, Frustulia rhomboides, Trachelomonas lacustris e Closterium acicularis foram correlacionadas com o aumento do nível hidrológico no período seco e chuvoso. Contrapondo, a densidade de Chlamydomonas sp., Chroomonas nordstedtii, Trachelomonas volvocinopsis, Trachelomonas volvocina e Synechococcus linearis foram correlacionadas com o aumento da transparência da água durante o período seco. De modo geral, a comunidade de algas perifíticas apresentou elevada diversidade e riqueza de espécies independentemente do período climático. O período climático apresentou pouca influência sobre a representatividade das classes algais e espécies descritoras. Contudo, os modelos sucessionais foram diferentes em cada período climático e as mudanças no nível hidrológico atuaram diretamente sobre a sucessão das algas perifíticas. Mais pesquisas sobre a dinâmica do perifíton são necessárias para melhorar a compreensão dos ecossistemas lacustres tropicais, especialmente na Amazônia.

PALAVRAS-ChaVE: Perifíton, colonização, sucessão, diversidade

\footnotetext{
Environmental Sciences Department, Universidade Federal do Acre, BR-364, km 4, 69915-900, Rio Branco, AC, Brazil

2 Ecology Section, Instituto de Botânica, Caixa Postal 4005, 01061-970, São Paulo, SP, Brazil (e-mail: carlaferragut@yahoo.com.br
} 


\section{INTRODUCTION}

Periphytic algal communities are the dominant primary producers and sources of autochthonous organic matter in most standing water, since most lakes and reservoirs are predominantly small and shallow (Wetzel 1996). Periphytic algae contribute largely to the biodiversity of these ecosystems, due to their high species richness (Lowe and Pan 1996). Periphytic algae also possess attributes that make them good indicators of environmental conditions, such as wide distribution in the aquatic environmental, sessile life cannot migrate in adverse conditions and spatially compacted with defined limits. Moreover, ecological information rich system because the high species diversity, algae possess relatively short life cycles (Lowe and Pan 1996; McCormick and Stevenson 1998).

Periphytic algal colonization and succession has been studied in a variety of aquatic environments and climatic regions (eg. McCormick and Stevenson 1991; Sekar et al. 2004; Vercellino and Bicudo 2006). While successional processes are well-researched in classical ecology, in the periphytic algal community, there is still a lack of understanding about the allogenic and autogenic factors that drive successional trajectories. Succession often begins with development of an organic matrix and bacterial flora, which is followed by a transition from small adnate diatoms to apically attached colonial diatoms and later to filamentous green algae (Biggs 1996). Recently, Zygnemaphyceae (Domozych and Domozych 2008) and Chlorophyceae (Sekar et al. 2004; Vercellino and Bicudo 2006; Ferragut and Bicudo 2009) were described as efficient pioneering colonizers based on their successional patterns. Knowledge of the succession in periphytic algal communities is still little, because of the complexity of development of natural autotrophic biofilm assemblages. Besides, the environmental factors that drive the dynamics of the periphyton in the Amazonian lakes are not known also.

Many studies have examined seasonal succession of periphyton in lentic systems and identified the influence of environmental variability on community organization (McCormick and Stevenson 1991; Cetto et al. 2004; Vercellino and Bicudo 2006). Changes in successional patterns in attached algal communities depend on a complex suite of interactions between physical habitat characteristics, allogenic biological constraints, such as grazing, autogenic changes in community condition, and species representation (Peterson 1996).

In general, studies on the succession of algae in tropical ecosystems are scarce, among which be prominent the observational studies of Vercellino and Bicudo (2006) and Rodrigues and Bicudo (2004). Vercellino and Bicudo (2006) told that the periphyton community was mainly controlled by the climatic period, the autogenic succession being of less importance. While Rodrigues and Bicudo (2004) observed that the flood pulse influenced the process sucessional of the periphytic algae. Specifically, colonization and succession of periphytic algal communities in Amazonian shallow lakes is little known. Previous research in the Amazon floodplain has shown the influences of riverine flooding on structure, nutrient status and productivity of periphyton, but did not examine the successional process (Engle and Melack 1993; Putz 1997; França et al. 2009).

Considering the importance of the periphytic community for shallow lakes function, the knowledge of the colonization process and successional patterns of a periphytic algal community may contribute to a better understanding of community dynamic. Therefore, we hypothesize that successional pattern of periphytic algae is driven primarily by the seasonal scale in one shallow Amazonian lake. The objective was to describe the successional pattern and identify the influence of seasonality and succession on community organization. This study investigated the development of the periphyton in the dry and rainy season shallow Amazonian Viveiro Lake.

\section{MATERIAL AND METHODS}

This study was conducted in a shallow, urban, tropical lake located in the Parque Zoobotânico of the Universidade Federal do Acre in Rio Branco, Brazil (0957' S and 67057' W). Locally called Viveiro Lake, it is actually a reservoir formed by the damming of a narrow river. It has a mean depth of about $1.75 \mathrm{~m}$ and a maximum depth of $2.7 \mathrm{~m}$. There are two distinct seasons in the region: rainy (October-May; $240 \mathrm{~mm}$ average accumulated precipitation) and dry (June-September; $61.7 \mathrm{~mm}$ average accumulated precipitation) (INMET 2009).

Water sampling for physical, chemical and biological analyses was conducted during the dry (August 19 to September 19 2006) and rainy (February 3 to March 8 2007) season. Sampling was performed in the morning over a period of 35 days; at 4-day intervals for 20 days, and then at 5-day intervals. Abiotic and biological sampling was carried out simultaneously in the pelagic region.

Surface water and periphyton samples were transported on ice in Styrofoam boxes to the Limnology Laboratory of the Department of Natural Sciences of the Universidade Federal do Acre. Abiotic variables analyzed included water transparency (Secchi disc), temperature, electrical conductivity, $\mathrm{pH}$, dissolved oxygen (DO) (Yellow Spring Instr., USA), alkalinity (Golterman and Clymo 1971), carbon dioxide (free $\mathrm{CO}_{2}$ ) (Mackereth et al. 1978), total nitrogen (TN) and total phosphorus (TP) concentration (Valderrama 1981), and silicate (Golterman et al. 1978). 
Glass slides (76 mm x $26 \mathrm{~mm}$ ) were used as artificial substrata for periphyton development. One hundred and fifty glass slides were fixed in wood bases and submerged to depths of $20 \mathrm{~cm}$. A total of 50 glass slides were removed periodically $(4,8,12,16,20,25,30$ and 35 days of exposure) for analysis of the periphytic community in each climatic period. Sampling of periphyton was performed through randomly drawing colonized slides. The periphyton was removed from the glass slides through scratching with razor blades and washing with distilled water.

Taxonomic material was preserved in a $4 \%$ formaldehyde water solution. Algal measurements were carried out according to Utermöhl (1958). Periphyton samples were preserved with Lugol's acid solution and stored in glass vials in a dark room until measurement. Sedimentation time in the chamber followed Lund et al. (1958). Samples were examined at 400x with a inverted microscope (Carl Zeiss, Axiovert, Germany) and counts of algal units (cells, colonies or filaments) were performed until at least 100 individuals had been counted for the most common taxa, and when counting of 10 consecutive fields yielded no new taxa not previously counted in the sample.

Biological indices were used as measure of community structure (Krebs 1999), including Shannon-Wiener diversity index (bits ind ${ }^{-1}$ ), dominance and evenness. Species richness was the total number of taxa found in each sample.

Descriptive and exploratory univariate analyses were performed using the software MINITAB version 10.1 (State College, Pennsylvania). A Coefficient of Variation (CV) was used to compare the degree of variation in environmental variables and periphytic community attributes studied over time. Multivariate descriptive analysis was performed by applying a Principal Component Analysis (PCA) to the abiotic and biotic data to a covariance matrix with log transformed data $(\mathrm{x}+1)$. For the Canonical Correspondence Analysis (CCA), abiotic and biological data were also log transformed $(x+1)$. PC-ORD version 3.0 for Windows was used for these analyses (McCune and Mefford 1997). A Monte Carlo test of significance based on 999 permutations was used to test the null hypothesis of no relationship between functional groups and environmental data.

\section{RESULTS}

\section{Abiotic Variables}

The table 1 summarize to limnologic condition of the dry and rainy season. Mean surface water temperature in the dry and rainy season was practically equal, and showed minimal temporal variability $(\mathrm{CV}$ : dry $=2.9 \%$; rainy $=3.6 \%)$. Mean $\mathrm{pH}$ values in each season were also very similar and showed little temporal variability $(\mathrm{CV}$ : dry $=2.1 \%$; rainy $=2.8 \%)$. In both seasons, electric conductivity was low and temporal variability was always low $(C V$ : dry $=6.2 \%$; rainy $=10.6 \%)$. In contrast, water transparency was higher in the dry season, but presented minimal temporal variability in both seasons (CV: $\mathrm{dry}=28.8 \%$; rainy $=27.8 \%)$. The highest values of free $\mathrm{CO}_{2}$ were registered during the dry season, and temporal variability was similar between seasons $(\mathrm{CV}$ : dry $=22.7 \%$; rainy $=22.9 \%$ ).

Highest TP values were registered during the dry season, which also showed the greatest variability $(\mathrm{CV}$ : dry $=128.3 \%$; rainy $=36.5 \%)$. TN concentration also showed increased temporal variability with the highest values recorded during the dry season $(\mathrm{CV}$ : dry $=75.1 \%$; rainy $=20.5 \%)$. The TN:TP molar ratio was high during the dry and rainy season (dry = 304 and rainy $=300$ on average), which indicated P limitation according to the Redfield ratio (16N:1P).

Table 1 - Limnological parameter ranges and, in between parenthesis, mean and standard deviation $(n=8)$ in the Viveiro Lake (Rio Branco, Acre-Brazil) during dry (August 19 to September 19 2006) and rainy (February 3 to March 8 2007).

\begin{tabular}{|c|c|c|}
\hline Variables & Dry Season & Rainy Season \\
\hline Alkalinity (mEq. $\mathrm{L}^{-1}$ ) & $0.22-0.40(0.29+0.05)$ & $0.17-0.30(0.24+0.05)$ \\
\hline Dissolved oxygen (mg. $\mathrm{L}^{-1}$ ) & $0.1-1.4(0.5 \pm 0.48)$ & $0.1-0.6(0.3 \pm 0.13)$ \\
\hline Electric conductivity $\left(\mu \mathrm{S} . \mathrm{cm}^{-1}\right)$ & $17-20(18 \pm 1.1)$ & $15-21(17 \pm 1.8)$ \\
\hline Free $\mathrm{CO}_{2}\left(\mathrm{mg} \cdot \mathrm{L}^{-1}\right)$ & $6.1-11.7(8.5 \pm 1.9)$ & $4.2-8.6(6.2 \pm 1.4)$ \\
\hline Silicate (mg.L-1) & $0.1-0.6(0.3 \pm 0.2)$ & $0.6-1.9(1.6 \pm 0.4)$ \\
\hline $\mathrm{pH}$ & $6.6-7.0(6.9 \pm 0.2)$ & $6.6-7.3(7.1 \pm 0.2)$ \\
\hline Temperature $\left({ }^{\circ} \mathrm{C}\right)$ & $25.6-27.8(26.6 \pm 0.8)$ & $25.5-27.9(26.5 \pm 0.9)$ \\
\hline Total nitrogen $(\mu \mathrm{g}$ TN.L-1) & $88-1,662(657 \pm 493.2)$ & $464-843(641 \pm 131.1)$ \\
\hline Total phosphorus ( $\mu \mathrm{g}$ TP. $\mathrm{L}^{-1}$ ) & $1.0-40(11.6 \pm 14.8)$ & $2.5-8.0(5.0 \pm 1.8)$ \\
\hline Transparency (Secchi Disc - m) & $0.4-0.9(0.7 \pm 0.2)$ & $0.2-0.5(0.4 \pm 0.1)$ \\
\hline TN:TP ratio (molar) & $18.5-770(304 \pm 267)$ & $162.1-581.4(300 \pm 144)$ \\
\hline
\end{tabular}




\section{Periphytic Community}

Total density of periphytic algae tended to increase in the dry and rainy season (Figure 1). In both seasons, the maximum value of total density was recorded on the 35 th day after colonization, but an exponential increase was evident only in the rainy season. The total density in the initial phase (Day 4) was 2.3 times larger in the dry season when compared with the rainy season, showing faster colonization of the substratum in the dry season. The temporal variation of the total density in the rainy season was higher than in the dry season $(\mathrm{CV}$ : dry $=17 \%$; rainy $=42 \%$ ).

Species richness and diversity values increased as succession progressed, with maximum values observed on the 25 and 35th day after colonization in the dry and rainy season, respectively (Figure 1a-b). The diversity index showed variation with exposure time, but increased exponentially only during the rainy season. On average, diversity and richness values were very similar between seasons. Evenness values did not show much variation over the exposure period, indicating relatively even species distribution (Figure 1c). Conversely, dominance values reduced gradually with succession during both the dry and rainy seasons (Figure 1d).

The evaluation of the taxonomic composition allowed identification of 254 taxa in the dry season and 182 in the rainy season. Zygnemaphyceae made up the largest
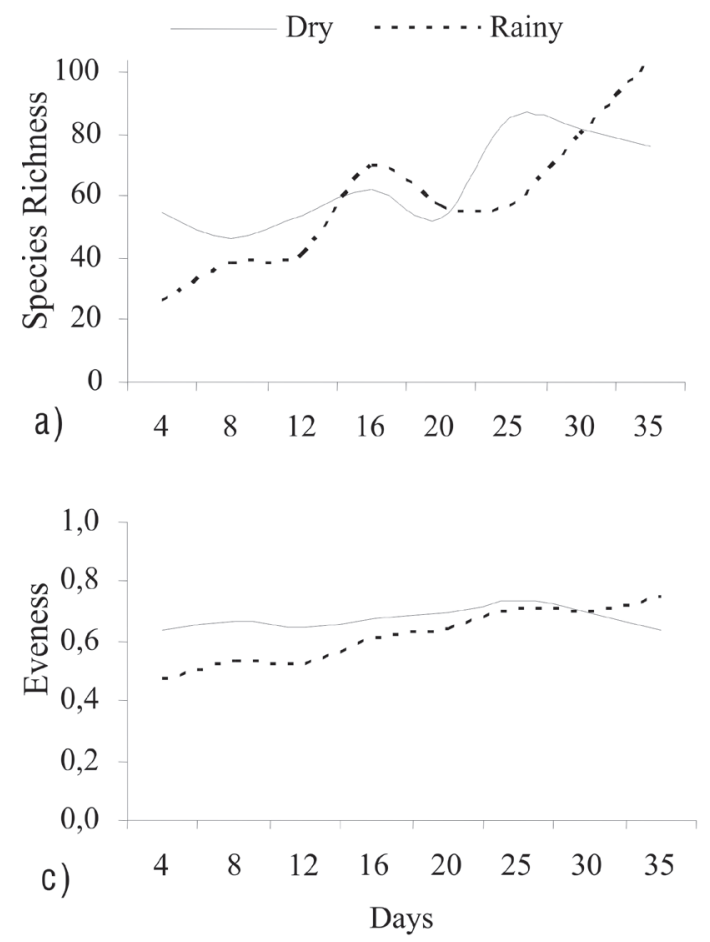

taxonomic group (128 taxa), followed by Euglenophyceae (62 taxa), Bacillariophyceae (40 taxa), Cyanobacteria (40 taxa), Chlorophyceae (33 taxa), Xanthophyceae (8 taxa), Dinophyceae (6 taxa), Cryptophyceae (5 taxa), Chrysophyceae (4 taxa), Chlamydophyceae (4 taxa) and Oedogoniophyceae (2 taxa).

Based on the species occurrence frequency, 153 rare, 62 common and 37 constant species were found in the dry season. In contrast, in the rainy season 91 rare, 79 common and 37 constant species were found.

Considering algae class density, Cyanobacteria showed the greatest representation during succession in both the dry season (43-67\%) and rainy season (51-84\%) (Figure 2). Despite overall dominance of Cyanobacteria during succession, an increase was observed in Bacillariophyceae, Euglenophyceae and Zygnemaphyceae as succession progressed. Seasonally, the representative algae classes were quite similar throughout the study period.

Community descriptive species were considered those with highest contribution (2\%) to total density in each successional stage (Figure 3). The species most representative in the periphytic community structure was Synechocystis aquatilis Sauvageau, which was abundant throughout the entire successional process in the dry season (28-43\%). This species
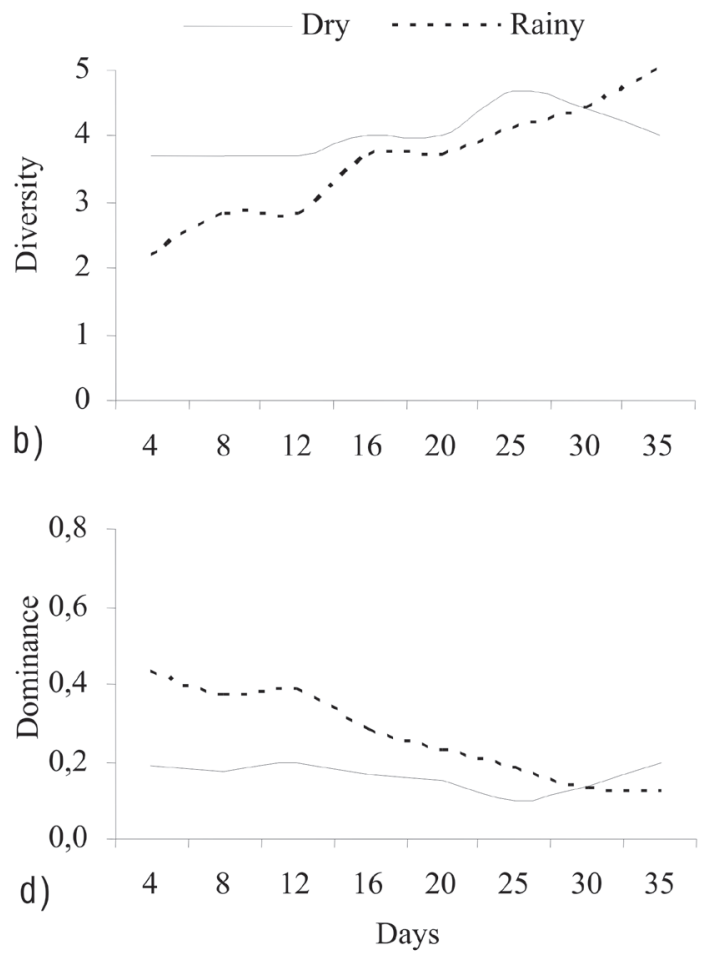

Figure 1 - Temporal variation of species richness (a), diversity (b), eveness (c) and dominance (d) of periphytic algae in Viveiro Lake (Rio Branco, Acre-Brazil) during the dry and rainy seasons 


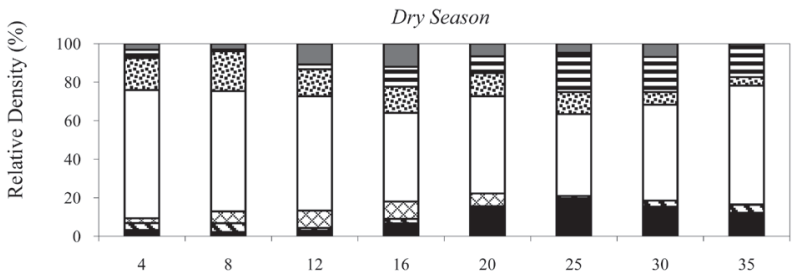

- Bacillariophyceae $\mathbf{D C h}$ Corophyceae $\mathbf{Q}$ Cryptophyceae $\square$ Cyanophyceae 田Euglenophyceae $\mathbf{Z}$ Zygnemaphyceae $\square$ Others

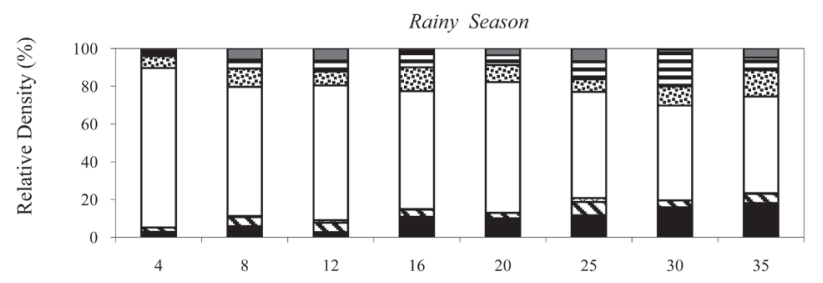

- Bacillariophyceae $\mathbf{\nabla}$ Chlorophyceae $\square$ Cryptophyceae $\square$ Cyanophyceae

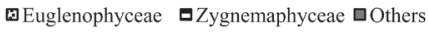

Figure 2 - Relative abundance of taxonomic classes of periphyton algae in Viveiro Lake (Rio Branco, Acre-Brazil) during the dry and rainy seasons was dominant in the rainy season until Day 16 (33-63\%). In general, the descriptive species presented high density in the initial successional stage and their density increased as succession progressed.

Trachelomonas volvocinopsis Swirenko var. volvocinopsis and Trachelomonas volvocina Ehrenberg var. volvocina were observed during initial successional stages (4-12 days) with high density in the dry season (Figure 3). Chlamydomonas sp. and Chroomonas nordstedtii Hansgirg var. nordstedtii increased during intermediate successional stages (Days 16-20), while diatoms Navicula pseudolanceolata Lang-Bertalot and Eunotia flexuosa Kützing were most abundant in the advanced stage (Days 25-35).

Community organization begins to change on the 16th day after colonization in the rainy season, with a high dominance of Synechocystis aquatilis (Figure 3).

The density of Aphanizomenon gracile Lemn. increased during the intermediate successional stage (Days 16-20), while Navicula pseudolanceolata, Closteriopsis acicularis (G.M. Smith) Belcher and Swale var. acicularis and Closterium acutum

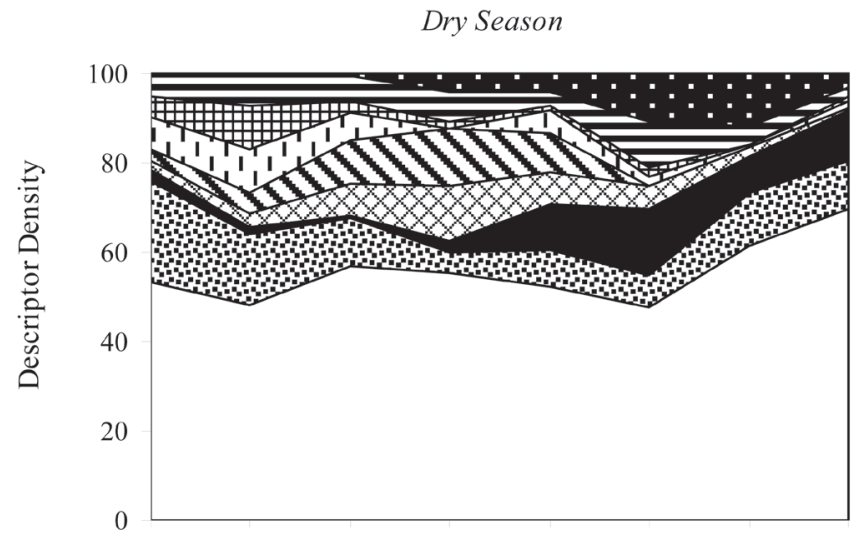

Rainy Season

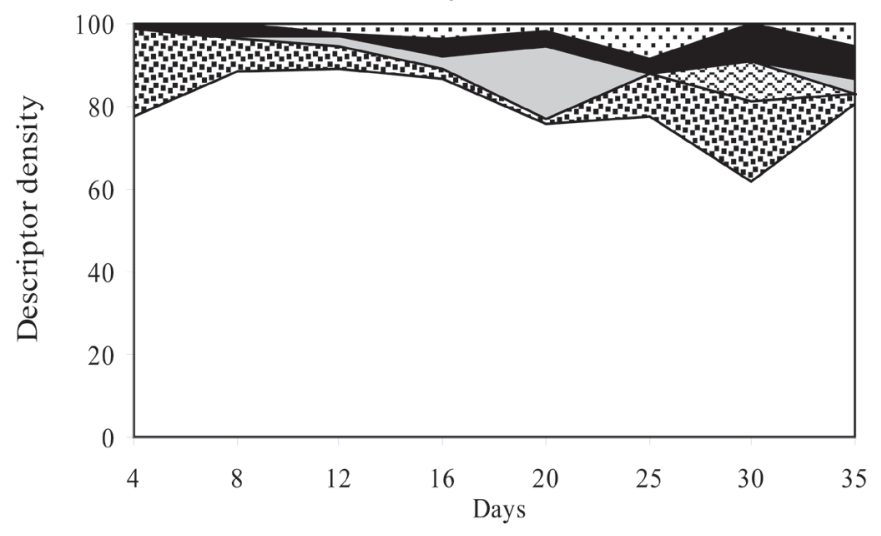

- Eunotia flexuosa

曰 Trachelomonas volvocina

田Trachelomonas volvocinopsis

$\square$ Synecoccocus linearis

曰 Chroomonas nordstedtii

O Chlamydomonas sp.

- Navicula pseudolanceolata

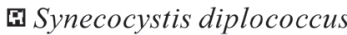

$\square$ Synecocystis aqualilis

घ Closteriopsis longissima

Navicula pseudolanceolata

$\square$ Aphanizomenon gracile

Closterium acutum var. acutum

⿴囗大 Synecocystis diplococcus

$\square$ Synecocystis aqualilis

Figure 3 - Temporal variation of relative abundance of the periphytic algae (total density $>5 \%$ each stage successional) in Viveiro Lake (Rio Branco, AcreBrazil) during dry and rainy seasons 
Brébisson ex Ralfs var. acutum contributed highly to total density during the advanced stage (Days 25-35) (Figure 3).

\section{Canonical Correspondence Analysis}

The ordination for the Canonical Correspondence Analysis of colonization in the dry and rainy season was performed with six abiotic variables and 24 abundant species (medium density ${ }^{3} 1.0 \%$ ) (Figure 4, Table 2).

To test the level of significance of the first two canonical axes, a Monte Carlo Test was used (999 permutations; $p$ $<0.05)$, which revealed that axes 1 and 2 were significant $(p$ $<0.05)$. The eigenvalues for axes $1(0.324)$ and $2(0.161)$ explained $36.1 \%$ of the biological data variance. The high species-environmental correlation for the axes 1 (0.954) and 2 (0.927) indicated a strong relationship between species distribution and environmental variables.

The canonical coefficient showed that the variable of higher weight in the ordination of the axis 1 was hydrologic level, which increased as a function of high precipitation during the rainy season. Total phosphorus concentration was the variable of greatest weight in the ordination of axis 2 .

The units samplers concerning the succession stages during dry season were located on the positive side of axis 1 , which were correlated to high values of water transparency $(r$ $=0.662), \mathrm{TP}(r=0.580)$, free $\mathrm{CO}_{2}(r=0.596)$, and electric conductivity $(r=0.554)$ (Figure 4). The succession stages of the rainy season were ordered on the negative side of the axis 1 , being highly correlated with the increase in hydrologic level $(r=-0.857)$. The ordination of succession stages occurred as a function of temporal variability of abiotic data and was influenced by seasonal events.

The ordination of periphytic algae showed that six species were highly correlated with the limnologic conditions of the dry season $\left(r^{3} 0.6\right)$, principally Synechocystis sp., Trachelomonas volvocinopsis var. volvocinopsis, Chroomonas nordstedtii, Trachelomonas volvocina var. volvocina, Chlamydomonas sp. and Synechococcus linearis (Schmilde et Lauterbon) Komárek (Figure 4, Table 2). In contrast, Cymbella tumida var. tumida (Brébisson ex Kützing) Grunow, Frustulia rhomboides (Ehrenberg) De Toni, Synechocystis diplococcus, Trachelomonas lacustris Drezepolski (non T. lacustris Skvortzov) var. lacustris and Closteriopsis var. acicularis were highly correlated $\left(r^{3}-0.5\right)$ with succession days during the rainy season.

The negative side ordered the sampling units of later successional stages in the dry season (Days 25-35), associated with higher density of Lyngbya sp., Navicula pseudolanceolata, Asterionella formosa Hassal and Eunotia flexuosa ( $r^{3}$ -0.6). These species were correlated with highest values of transparency during the dry season.

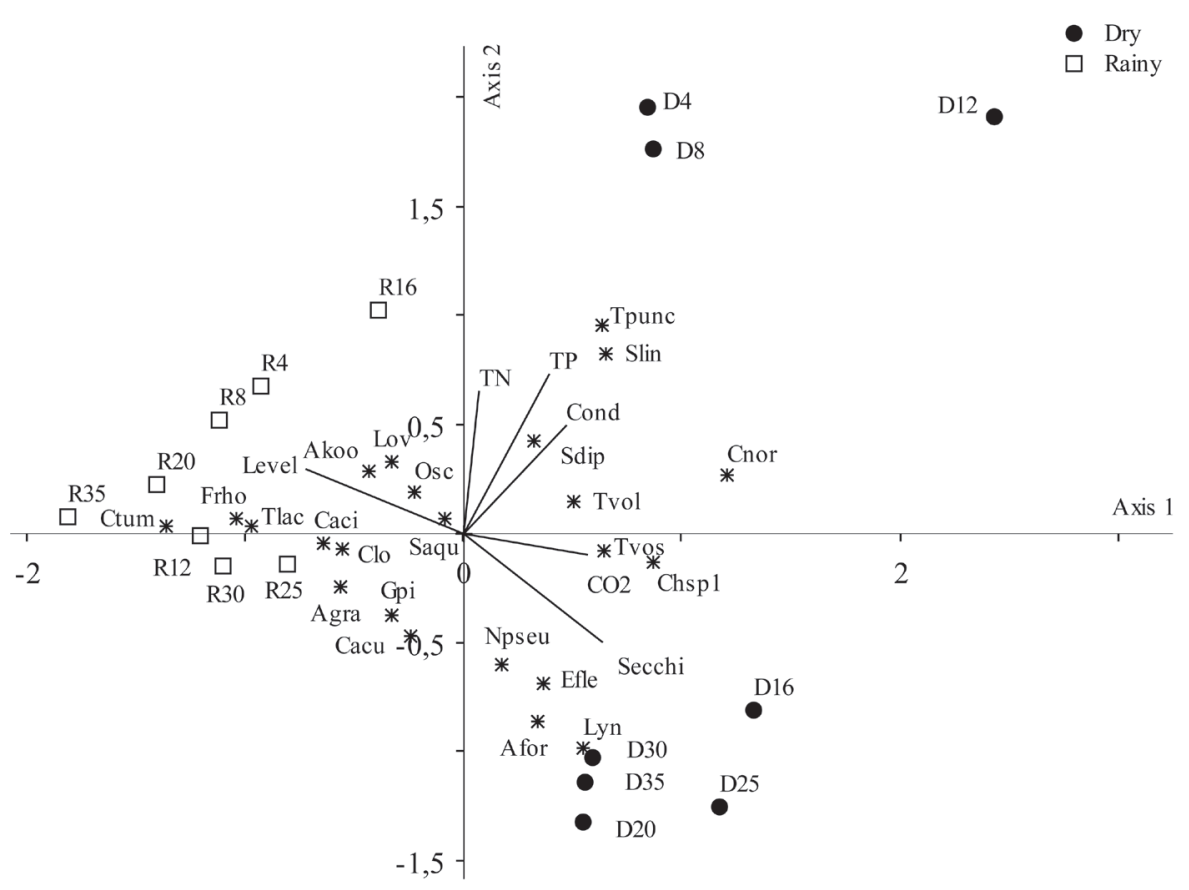

Figure 4 - CCA ordination of sampling units of periphyton succession in Viveiro Lake (Rio Branco, Acre-Brazil) during the dry and rainy seasons. Scores abbreviations: letter refer to season $\left(\mathrm{D}=\mathrm{dry} ; \mathrm{R}=\right.$ rainy); numbers represent successional days. (Abbreviations: Depth = hydrological level; $\mathrm{CO2}=$ free $\mathrm{CO}_{2}$; Cond $=$ conductivity; Secchi $=$ transparency; $\mathrm{DO}=$ dissolved oxygen; $\mathrm{pH}=\mathrm{pH} ; \mathrm{TP}=$ total phosphorus; $\mathrm{TN}=$ total nitrogen; Temp = temperature). Species codes are in Table 4 
Table 2 - Pearson correlations of periphytic algae of Viveiro Lake (Rio Branco, Acre-Brazil) with axis 1 and 2 of the Canonical Correspondence Analysis (CCA), and the respective code of the species and growth forms (unicellular, flagellate, filamentous, and colonial).

\begin{tabular}{|c|c|c|c|c|}
\hline & Life Forms & Code & Axis 1 & Axis 2 \\
\hline Asterionella formosa & Unicellular & Afor & 0.213 & -0.660 \\
\hline Aphanizomenon gracile & Filamentous & Agra & -0.226 & -0.153 \\
\hline Aphanocapsa koordersi & Colonial & Akoo & -0.316 & 0.129 \\
\hline $\begin{array}{l}\text { Closteriopsis acicullaris var. } \\
\text { acicullaris }\end{array}$ & Unicellular & Caci & -0.467 & -0.118 \\
\hline Closteriopsis Iongissima & Unicellular & $\mathrm{Clo}$ & -0.378 & -0.135 \\
\hline $\begin{array}{l}\text { Closterium acutum var. } \\
\text { acutum }\end{array}$ & Unicellular & Cacu & -0.120 & -0.254 \\
\hline Chlamydomonas sp. & Flagellate & Chsp1 & 0.599 & -0.319 \\
\hline Chroomonas nordstedtii & Flagellate & Cnor & 0.619 & -0.012 \\
\hline Cymbela tumida & Unicellular & Ctum & -0.524 & 0.036 \\
\hline Eunotia flexuosa & Unicellular & Efle & 0.259 & -0.662 \\
\hline Frustulia rhomboides & Unicellular & Frho & -0.556 & 0.037 \\
\hline Gonatozygon pilosum & Filamentous & Gpi & -0.231 & -0.363 \\
\hline Lepocinclis ovum & Flagellate & Lov & -0.170 & 0.225 \\
\hline Lyngbya sp. & Filamentous & Lyn & 0.278 & -0.629 \\
\hline Navicula pseudolanceolata & Unicellular & Npseu & 0.194 & -0.660 \\
\hline Oscillatoria sp. & Filamentous & Osc & -0.147 & 0.095 \\
\hline Synechocystis aquatilis & Colonial & Saqu & 0.006 & -0.042 \\
\hline Synechocystis diplococcus & Colonial & Sdip & -0.557 & 0.025 \\
\hline Synechocystis sp. & Colonial & Syn & 0.785 & 0.283 \\
\hline Synechococcus linearis & Unicellular & Slin & 0.596 & 0.534 \\
\hline $\begin{array}{l}\text { Trachelomonas lacustris var. } \\
\text { lacustris }\end{array}$ & Flagellate & Tlac & -0.462 & 0.015 \\
\hline $\begin{array}{l}\text { Trachelomonas } \\
\text { volvocinopsis var. punctata }\end{array}$ & Flagellate & Tpunc & 0.475 & 0.513 \\
\hline $\begin{array}{l}\text { Trachelomonas volvocina } \\
\text { var. volvocina }\end{array}$ & Flagellate & Tvol & 0.618 & -0.034 \\
\hline $\begin{array}{l}\text { Trachelomonas } \\
\text { volvocinopsis var. } \\
\text { volvocinopsis }\end{array}$ & Flagellate & Tvos & 0.629 & -0.236 \\
\hline
\end{tabular}

\section{DISCUSSION}

The dynamics of tropical lakes is controlled by seasonality, which is principally expressed by alterations in hydrologic regimes and their influence on the physical chemistry of water variable (Amoros and Bornette 2002). Although Viveiro Lake is not connected with the river, limnologic conditions during the study period differed seasonally. The rainy season was characterized by an increase in hydrologic level, while the dry season was characterized by lower depth and higher water transparency. Clearly, hydrologic level was the main driver of temporal variability in environmental variables. The water temperature didn't influence anything because the annual variation of this variable is very small. Several previous studies also documented periphyton responses to these conditions in tropical floodplain lakes in the Amazon (Engle and Melack 1993; Putz 1997; França et al. 2009).

Seasonality influenced the variability of biological indexes, but throughout succession, the maximum values were similar, particularly of diversity and evenness. The influence of seasonality on diversity and species richness has been observed in tropical reservoirs (Cetto et al. 2004; Vercellino and Bicudo 2006). Vercellino and Bicudo (2006) found relatively stable and similar diversity values throughout succession and in the dry and rainy season.

Independent of seasonality, periphyton community structure showed a successional pattern of high diversity and species richness. Species diversity and richness increased with colonization time, reaching maximum values in the more advanced successional phases (Days 20-25). Previous studies in tropical lentic systems also showed an increase in diversity with community development (Rodrigues and Bicudo 2004; Ferragut and Bicudo 2009). And others reported high diversity in intermediate phases of succession (Vercellino and Bicudo 2006). In temperate oligotrophic lakes, McCabe and Cyr (2006) suggested that increases in environmental variability can lead to higher diversity in benthic algal communities. Therefore, the periphytic algal community that developed in Viveiro Lake increased in structural complexity as succession progressed from time of colonization, independent of variations in hydrologic level.

The taxonomic structure of the periphytic algal community showed high occurrence of Cyanobacteria during succession in both dry and rainy seasons, especially for the species Synechocystis aquatilis. This reflects findings of previous studies, which also found a high incidence of Cyanobacteria in advanced successional phases (Fonseca and Rodrigues 2007; Gottlieb et al. 2006; Borduqui et al. 2008).

The oligotrophic conditions of Viveiro Lake allowed the success of Cyanobacteria as efficient colonizers, principally in the initial and intermediate successional phases. Synechocystis aquatilis and Synechocystis diplococcus were the primary colonizers. These genera are cosmopolitan and extremely common in oligotrophic systems (Paerl 1988; Reynolds 1997). Comparatively, Cyanobacteria density was lower in the dry season, but maintained a high representation in both climatic periods. This fact can likely be explained by the maintenance of low nutrient availability, mainly phosphorus (on average $12 \mu \mathrm{g}$.

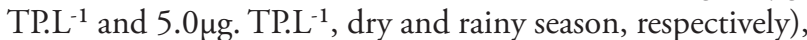
in spite of the increase in hydrologic level during the rainy season. Moreover, França et al. (2009) reported that the community in Viveiro Lake was limited by phosphorus with based on periphyton nutrient status. Therefore, high growth of Cyanobacteria picoperiphytic $(<10 \mu \mathrm{m})$ was observed in 
condition of low nutrients availability in water, and high for P limitation of periphyton.

Synechocystis aquatilis was the dominant phytoplankton species in Viveiro Lake during the dry and rainy season (Dantas 2008). Carrick and Steinman (2001) did not consider Synechococcus a true periphyton, because this species occurred in the water column throughout the year. In agreement with Margalef (1998) a tenuous limit exists between the phytoplanktonic and periphytic communities.

Another important class in the periphytic community structure was Euglenophyceae, constituted principally by Trachelomonas volvocina var. volvocina and Trachelomonas volvocinopsis var. volvocinopsis. These species were abundant in the dry season and they were correlated with an increase in water transparency. In the tropical oligotrophic system, Vercellino and Bicudo (2006) found Trachelomonas hispida in periphytic habitats as community descriptor during dry and rainy season.

Zygnemaphyceae, especially Desmidiaceae, was the class with the highest species number and occurrence in community organization of Viveiro Lake during the dry and rainy season. Studies in freshwater wetlands showed an ability of desmids to produce prolific amounts of matrix polysaccharide complex, which were associated with high quantities of bacteria (Domozych et al. 1993; Domozych and Domozych 2008). According to Coesel (1996), true planktonic Desmidiaceae are rare, because most use the substratum for reproduction. Desmidiaceae also prefers habitat with $\mathrm{pH}$ among acid to neutral, as do most of the species associated with oligotrophic systems (Coesel 1982). Such limnologic characteristics were also observed in Viveiro Lake, what promoted the success of this class in terms of richness of species. Only in the rainy season one specie the community's descriptor was considered, Closterium acutum var. acutum during advanced successional phase.

The diatom increased in occurrence in community structure as succession progressed during dry and rainy season, but this class was abundant only in the advanced phases. The diatoms are considered fast and efficient colonizers and most species have specialized fixation structures to attach to the substratum (Biggs 1996). This class is described as an efficient pioneering colonizer in lotic systems (Ács and Kiss 1993). Navicula pseudolanceolata was found in high occurrence in the initial succession phase in the dry and rainy season. This species was also observed among the pioneering colonizers in other tropical reservoirs (Felisberto and Rodrigues 2005). Specifically, in the dry season, Eunotia flexuosa had high occurrence in the advanced successional phase. According to van Dam et al. (1994) the genera Eunotia is an indicative fort of acid, oligotrophic waters and rich in oxygen.
In tropical reservoirs, Cetto et al. (2004) registered wide diatom dominance in the periphyton in the dry and rainy seasons, which was favored by high competitive capacity in conditions of low availability of light and nutrients. Similarly, in the present study, Eunotia flexuosa, Navicula pseudolanceolata, and Asterionella formosa were correlated with higher values of water transparency in the dry season. While Frustulia rhomboides was associated with increased hydrologic level, which may have favored the re-suspension of the species that is related to the epipelic habitat (Siver and Baskette 2004).

In general, three species were constant in the structure of the periphytic community in the two seasons: Synechocystis aquatilis, S. diplococcus and Navicula pseudolanceolata. These species possess efficient adaptive strategies to grow in oligotrophic systems (Reynolds 1997; van Dam et al. 1994). The main community descriptive species did not vary seasonally, but their successional trajectory changed in function of hydrologic level. Putz (1997) found diatom dominance in Amazonian black and white-water habitats, but did not observe seasonal change in species composition. Conversely in temperate region, Sekar et al. (2004) observed seasonal variation in species composition, but the sequence of colonization was similar throughout the study period.

Canonical Correspondence Analysis showed the influence of seasonality on the structure of periphytic algae community, indicating that hydrologic level and water clarity were the most important variables in the ordering of the species. Cymbela tumida, Frustulia rhomboides and Trachelomonas lacustris and Closterium acicularis were highly correlated with an increase in hydrologic level during the rainy season. Conversely, Chlamydomonas sp., Chroomonas nordstedtii, Trachelomonas volvocinopsis, Trachelomonas volvocina and Synechococcus linearis were correlated with an increase in water transparency during the dry season. Therefore, the multivariate analysis reduced data dimensionality, showing the influence of hydrologic level on successional trajectories of the periphytic algal community in the seasonal scale.

Finally, successional patterns of the periphytic algal community identified in Viveiro Lake presented high diversity and species richness independent of season. Cyanobacteria was the most abundant taxonomic class in the dry and rainy seasons, and the most abundant species were strategists $\mathrm{R}$ (sensu Reynolds 1997). Synechocystis aquatilis was the most abundant species in both seasons, followed by $S$. diplococcus and Navicula pseudolanceolata. During advanced successional stages in the rainy season, there was a high occurrence of Closterium acutum var. acutum, Aphanizomenon gracile Closteriopsis longissima Lemmermann. Cymbela tumida, Frustulia rhomboides e Trachelomonas lacustris and Closterium acicularis were associated with the highest hydrologic level. Conversely, dry season Chlamydomonas sp., Chroomonas 
nordstedtii, Synechococcus linearis, Trachelomonas volvocinopsis, Trachelomonas volvocina and Eunotia flexuosa were the most common species in the advanced successional stages and the five species (Chlamydomonas sp., Chroomonas nordstedtii, Trachelomonas volvocinopsis, Trachelomonas volvocina and Synechococcus linearis) were primarily correlated with an increase of water transparency. Therefore, seasonality did not change the community structure in terms of algae class and species abundance. However, the successional patterns of the periphytic algae community varied seasonally, because hydrologic level and water transparency changes influenced successional trajectories. This study is the first to describe the successional process of periphytic algal communities in Amazonian lakes. More research on periphyton dynamics is needed to improve our understanding of tropical lake ecosystems, especially in Amazonian.

\section{ACKNOWLEDGEMENTS}

The authors are grateful to the Ford Foundation for the masters degree scholarship awarded to the first author and to Nadir de Souza Dantas for her collaboration in the collection and analysis of data.

\section{LITERATURE CITED}

Ács, E.; Kiss, K.T. 1993. Colonization processes of diatoms on artificial substrates in the River Danube near Budapest (Hungary). Hydrobiologia, 269/270: 307-315.

Amoros, C.; Bornette, G. 2002. Connectivity and biocomplexity in riverine floodplains. Freshwater Biology, 47: 761-776.

Biggs, B.J.F. 1996. Patterns in benthic algae of streams, p 31-56. In: Stevenson, R.J.; Bothwell, M.L.; Lowe, R.L. (Eds). Algal Ecology: freshwater benthic ecosystems. Academic Press, USA.

Borduqui, M.; Ferragut, C.; Bicudo, C.E.M. 2008. Chemical composition and taxonomic structure vertical and seasonal variation of periphyton community in a shallow hypereutrophic reservoir (Garças Reservoir, São Paulo, Brazil). Acta Limnologica Brasiliensia, 20: 381-392.

Carrick, H.J.; Steinman, A.D. 2001. Variation in periphyton biomass and species composition in Lake Ockeechobee, Florida (USA): distribution of algal guilds along environmental gradients. Archives für Hydrobiologie, 152(3): 411-438.

Cetto, J.M.; Leandrini, J.A.; Felisberto, A.S.; Rodrigues, L. 2004. Periphyton algae community in Irai reservoir, Paraná state, Brazil. Acta Scientiarum Biological Science, 26: 1-7.

Coesel, P.F.M. 1982. Structural characteristics and adaptations of desmid communities. Journal of Ecology, 70: 163-177.

Coesel, P.F.M. 1996. Biogeography of desmids. Hydrobiologia, 336: 41-53.

Dantas, N.S. 2008. Influences of abiotic variables in the structure and dynamics in the phytoplankton community in a shallow artificial lake. Dissertação de Mestrado, Universidade Federal do Acre, Rio Branco, Acre. 71 pp. (in Portuguese).
Domozych, C.R.; Plante, K.; Blais, P.; Paliulis, L.; Domozych, D.S. 1993. Mucilage processing and secretion in the green alga Closterium. I. Cytology and biochemistry. Journal of Phycology, 29: 650-659.

Domozych, D.S.; Domozych, C.R. 2008. Desmids and Biofilms of Freshwater Wetlands: Development and Microarchitecture. Microbial Ecology, 55: 81-93.

Engle, D.L.; Melack, J.M. 1993. Consequences of riverine flooding for seston and the periphyton of floating meadows in Amazon floodplain lake. Limnology \& Oceanography. Archiv für Hydrobiologie, 38: 1500-1520.

Felisberto, S.A.; Rodrigues, L. 2005. Community of periphytic algae in reservoir of different latitudes, p. 97-114. In: Rodrigues, L.; Thomaz, S.M.; Agostinho, A.A.; Gomes, L.C. (Org.). Biocenoses em Reservatórios: padröes espaciais e temporais. Ed. Rima. São Carlos.

Ferragut, C.; Bicudo, D.C. 2009. Effect of different levels of phosphorus enrichment on periphyton community structure in a tropical oligotrophic reservoir (São Paulo, Brazil). Revista Brasileira de Botânica, 32: 569-583.

Fonseca, I.A.; Rodrigues, L. 2007. Periphytic Cyanobacteria in different environments from the upper Paraná river floodplain, Brazil. Acta Limnologica Brasilensia, 191: 53-65.

França, R.C.S.; Lopes, M.R.M.; Ferragut, C. 2009. Temporal variation of biomass and status nutrient of periphyton in shallow Amazonian lake (Rio Branco, Brazil). Acta Limnologica Brasilensia, 21(2): 175-183.

Golterman, H.L.; Clymo, R.S. 1971. Methods for chemical analysis offreshwaters. Oxford: Blackwell Scientific Publications. 166 pp.

Golterman, H.L.; Clymo, R.S., Ohmstad, M.A.M. 1978. Methods for physical and chemical analysis of freshwater. Oxford: Blackwell Scientific Publications, 213 pp.

Gottlieb, A.D.; Richards, J.H.; Gaiser, E.E. 2006. Comparative study of periphyton community structure in long and shorthydroperiod Everglades marshes. Hydrobiologia, 569: 195-207.

INMET, 2009. Instituto Nacional de Meteorologia (www.inmet. gov.br). Acesso: 1/06/2008.

Krebs, C.J. 1999. Ecological Methodology. Addisson Wesley Longman, Menlo Park.

Lowe, R.L.; Pan, Y. 1996. Periphyton patterns in lakes, p. 57-76. In: Stevenson, R.J.; Bothwell, M.L.; Lowe, R.L. (Eds). Algal Ecology: freshwater benthic ecosystem. Academic Press, USA.

Lund, J.W.G.; Kipling, C.; Le Cren, E.D. 1958. The inverted microscope method of estimating algal numbers and statistical basis of estimation by counting. Hydrobiologia, 11: 143-170.

Mackereth, F.J.H.; Heron, J.; Talling, J.F. 1978. Water analysis: some revised methods for limnologists. Kendall: Titus Wilson and Son Ltda. 117 pp.

Margalef, R. 1998. La imprecisa frontera entre el plâncton y otros tipos de comunidades, p. 319-326. In: Azevedo, M.T.P. et al. (Eds). Anais do $7^{\circ}$ SPFic, Caxambu. 
McCabe, S.K.; Cyr, H. 2006. Environmental variability influences the structure of benthic algal communities in an oligotrophic lake. Oikos, 115: 197-206.

McCormick, P.V.; Stevenson, R.J. 1991. Mechanisms of benthic algal succession in different flow environments. Ecology, 72: 1835-1848.

McCormick, P.V.; Stevenson, R.J. 1998. Periphyton as a tool for ecological assessment and management in the Florida Everglades. Journal of Phycology, 34: 726-733.

McCune, B.; Mefford, M.J. 1999. PC-ORD. Multivariate analysis of ecological data, version 3.0. MjM Software Design, Oregon. $47 \mathrm{pp}$.

Paerl, H.W. 1988. Growth and reproductive strategies of freshwater blue-green algae (Cyanobacteria), p. 134-174. In: Sandgren, C.G. (Ed.). Growth and reproductive strategies of freshwater phytoplankton. Cambridge, Cambridge University Press.

Peterson, C.G. 1996. Response of benthic algal communities to natural physical disturbance, p 375-403. In: Stevenson, R.J.; Bothwell, M.L.; Lowe, R.L. (Eds). Algal Ecology: freshwater benthic ecosystems. Academic Press, USA.

Putz, R. 1997. Periphyton communities in Amazonian black and whitewater habitats: community structure, biomass and productivity. Aquatic Science, 50: 74-93.

Reynolds, C.S. 1997. Vegetation processes in the pelagic: a model for ecosystem theory. Ecology Institute, Germany. $371 \mathrm{pp}$.
Rodrigues, L.; Bicudo, D.C. 2004. Periphytic algae, p. 125-143. In: Thomaz, S.M.; Agostinho A.A. \& Hahn, N.S. (Eds). The upper paraná river and its floodplain: physical aspects, ecology and conservation. Leiden, The Netherlands, Backhuys Publishers.

Sekar R.; Nair, K.V.K.; Nandakumar, K.; Venugopalan, V.P.; Rao, V.N.R. 2004. Early stages of biofilm succession in a lentic freshwater environment. Hydrobiologia, 512: 97-108.

Siver, P.A.; Baskette, G. 2004. A morphological examination of Frustulia (Bacillariophyceae) from the Ocala National Forest, Florida, USA. Canadian Journal of Botany, 82: 629-644.

Valderrama, G.C. 1981. The simultaneous analysis of total nitrogen and total phosphorus in natural waters. Marine Chemical, 10: 109-112.

van Dam, H.; Mertens, A.; Sinkeldam, J. 1994. A coded and ecological indicator values of freshwater diatoms from the Netherlands. Journal of Aquatic Ecology, 28: 117-133.

Vercellino, I.S.; Bicudo, D.C. 2006. Periphytic algal community succession in a tropical oligotrophic reservoir (São Paulo, Brazil): comparison between dry and rainy periods. Revista Brasileira de Botânica, 29: 363-377.

Wetzel, R.G. 1996. Benthic algae and nutrient cycling in lentic freshwater ecosystems, p 641-667. In: Stevenson, R.J.; Bothwell, M.L.; Lowe, R.L. (Eds). Algal Ecology: freshwater benthic ecosystems. Academic Press, USA.

Recebido em 16/02/2010

Aceito em 12/08/2010 